University of Nebraska - Lincoln

DigitalCommons@University of Nebraska - Lincoln

USDA Forest Service / UNL Faculty Publications U.S. Department of Agriculture: Forest Service --

National Agroforestry Center

2005

\title{
AMS Dates from Four Late Prehistoric Period Rock Art Sites in West Central Montana
}

Sara A. Scott

Helena National Forest, sarascott01@fs.fed.us

Carl M. Davis

Helena National Forest, cmdavis@fs.fed.us

Karen L. Steelman

University of Central Arkansas, ksteel@uca.edu

Marvin W. Rowe

Texas A\&M University, rowe@mail.chem.tamu.edu

Tom Guilderson

Lawrence Livermore National Laboratory, tguilderson@llnl.gov

Follow this and additional works at: https://digitalcommons.unl.edu/usdafsfacpub

Part of the Forest Sciences Commons

Scott, Sara A.; Davis, Carl M.; Steelman, Karen L.; Rowe, Marvin W.; and Guilderson, Tom, "AMS Dates from Four Late Prehistoric Period Rock Art Sites in West Central Montana" (2005). USDA Forest Service / UNL Faculty Publications. 169.

https://digitalcommons.unl.edu/usdafsfacpub/169

This Article is brought to you for free and open access by the U.S. Department of Agriculture: Forest Service -National Agroforestry Center at DigitalCommons@University of Nebraska - Lincoln. It has been accepted for inclusion in USDA Forest Service / UNL Faculty Publications by an authorized administrator of DigitalCommons@University of Nebraska - Lincoln. 


\title{
AMS Dates from Four Late Prehistoric Period Rock Art Sites in West Central Montana
}

\author{
Sara A. Scott, Carl M. Davis, Karen L. Steelman, Marvin W. Rowe, and Tom Guilderson
}

In 2002, eight pigment samples were collected from three rock art sites in the Big Belt Mountains of west central Montana. Samples from Hellgate Gulch (24BW9), Avalanche Mouth (24BW19), and the Gates of the Mountains (24LC27) were dated using plasma-chemical extraction and accelerator mass spectrometry. The dates were statistically indistinguishable with ages of $1170 \pm 45,1225 \pm 50$, and 1280 \pm 50 B.P. When calibrated, these ages range from 650 to $990 \mathrm{cal}$ A.D. This corresponds to the early Late Prehistoric period on the Northwestern Plains. An oxalate accretion sample overlying a painted area at another site, Big Log Gulch (24LC1707), provided a minimum age of $1440 \pm 45$ B.P. for the rock art present at this site. The dated images at the four sites fit within the Foothills Abstract and Eastern Columbia Plateau rock art traditions.

\section{Keywords: rock art, plasma-chemical extraction, radiocarbon dating, Foothills Abstract tradition, Eastern Columbia Plateau tradition}

Since 1997, the Helena National Forest has maintained an active rock art research and conservation program in the Big Belt Mountains of west central Montana (Greer and Greer 1997, 2001; Loubser 2001a, 2002, 2004; Scott and Davis 2004; Scott et al. 2000). Natural deterioration, vandalism and increased site visitation necessitated the development of conservation plans and accurate baseline data for monitoring and law enforcement purposes. Two of the largest Big Belts rock art sites in Hellgate Gulch (24BW9) and the Gates of the Mountains (24LC27) are now recorded in detail, and graffiti has been removed from the Hellgate Gulch site to discourage future vandalism (Loubser 2001a; Scott et al. 2000). A large forest fire in the north Big Belts in 2000 precipitated post-fire erosion control at the
Hellgate Gulch pictographs (Davis 2001; Scott et al. 2000), rock art survey in the burn area (Greer and Greer 2001), and site condition assessments (Loubser 2001a). The accelerator mass spectrometry (AMS) dating project with Texas A\&M University and Lawrence Livermore National Laboratory described in this paper is a continuation of this rock art investigation program.

Only a few attempts have been made to date central Montana rock art using AMS radiocarbon dating (Greer 1995: 48-50; Loendorf 1992). Paint pigment seriation has therefore been used to establish a relative chronology for central Montana rock art, which spans from 3000 B.C. to A.D. 1000 (Greer 1995). The notable absence of Ceremonial tradition and Biographic tradition rock art images also

Sara A. Scott, USDA-Forest Service, Helena National Forest, 2880 Skyway Drive, Helena, MT 59602. sascott01@fs.fed.us

Carl M. Davis, USDA-Forest Service, Helena National Forest, 2880 Skyway Drive, Helena, MT 59602. cmdavis@fs.fed.us

Karen L. Steelman, Department of Chemistry, University of Central Arkansas, Conway, AR 72035. ksteel@uca.edu

Marvin W. Rowe, Department of Chemistry, Texas A\&M University, P.O. Box 30012, College Station, TX $77842-3012$. rowe@mail.chem.tamu.edu

Tom Guilderson, Center for Accelerator Mass Spectrometry, Lawrence Livermore National Laboratory, Livermore, CA 94550.tguilderson@llnl.gov 


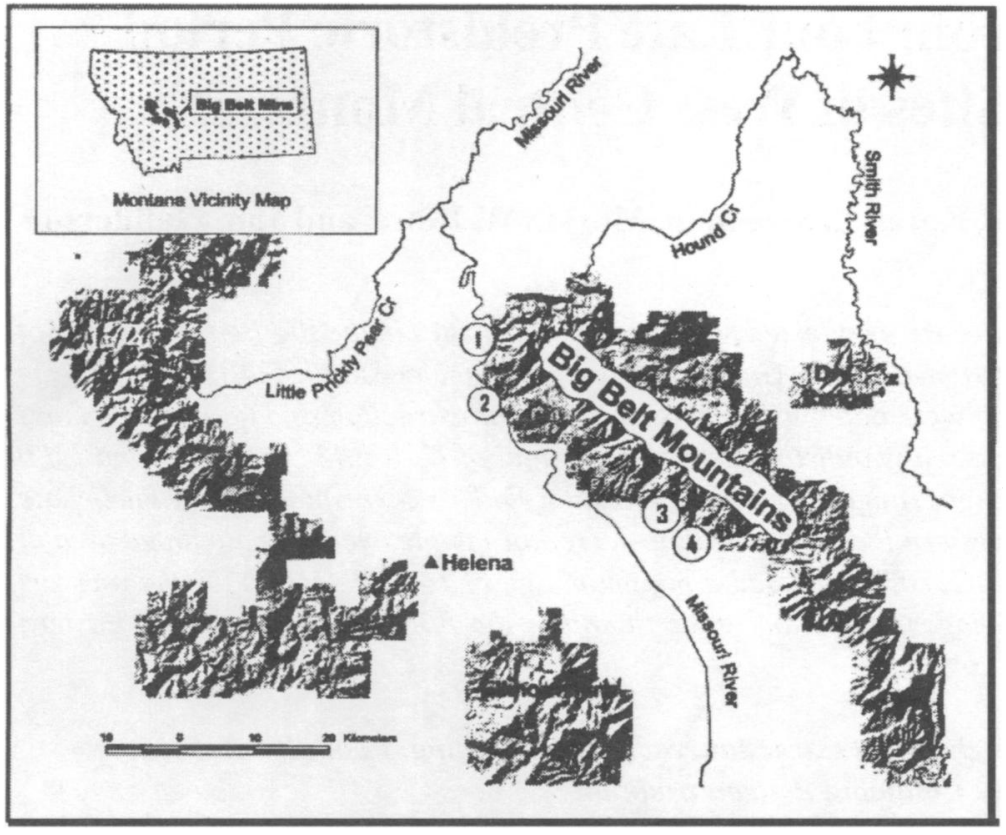

Figure 1. Map of west-central Montana showing rock art locations: 1) Gates of the Mountains/24LC27, 2) Big Log Gulch/24LC1707, 3) Hellgate Gulch/24BW9, and 4) Avalanche Mouth/24BW19.

indicates that many central Montana rock art sites pre-date A.D. 1000. Although these are useful temporal reference points, radiocarbon dates are necessary to build an accurate rock art chronology.

Rock art condition assessments completed by Loubser (2001a, 2002) identified images at four sites that were in deteriorated condition and flaking from the rock face. In 2002, small flakes of paint pigment exfoliating from the panels at these select sites were carefully collected for AMS radiocarbon dating. An oxalate accretion sample overlying a red pigment smear was also collected from the Big Log Gulch Pictograph site (24LC1707). In an effort to be sensitive to potential tribal and rock art conservation concerns, samples were not removed from intact (non-exfoliating) images, although such sampling may have provided finer temporal and stylistic resolution to this study.

\section{ROCK ART CONTEXT AND SAMPLE SITES}

The Big Belt Mountains lie just east of the Continental Divide on what is roughly the boundary between the Eastern Columbia Plateau and the Northwestern Plains. The majority of pictograph sites in the Big Belts (and surrounding mountain ranges) are characteristic of the Foothills Abstract rock art tradition (Keyser and Klassen 2001:151-175). This tradition, which may have originated in the Middle Plains Archaic period, is characterized by extensive red pigment washes with superimposed images composed of elongated (stick-like) human figures, zoomorphs, handprints, smears, fingerlines, maze and mask-like figures, and geometric designs. Foothills Abstract pictographs are frequently scratched, and some may have been repainted. Characteristic images occur at sites as single compositions or in small groups of juxtaposed images (Keyser and Klassen 2001:162).

Images typical of the Eastern Columbia Plateau rock art tradition-zigzag lines, tally marks, rayed circles, crosses, and animal and human-like figures-also occur in the Big Belts (Keyser 1992). These images are often structured to symbolize the relationship between humans, animals, and the spirit world. Eastern Columbia Plateau tradition rock art is less abundant in this area and appears to occur later than Foothills Abstract images based on the superimpositioning of figures at the Gates of the Mountains site, 24LC27 (Loubser 2004:77).

The relationship between these two distinct rock art traditions in this region is far from clear. The traditions share some figure types, such as animal and human images, making it difficult to ascribe certain images to one particular tradition. However, rock art at all sites in the Big Belts is strongly correlated with steep limestone cliffs and is commonly found near canyon mouths. Pictograph paint colors range from deep red to orange. Rock art research conducted in this area indicates that shamans and vision quest seekers likely produced the bulk of this central Montana art (Greer and Greer 2003; Keyser and Klassen 2001:167-173; Loubser 2004). 


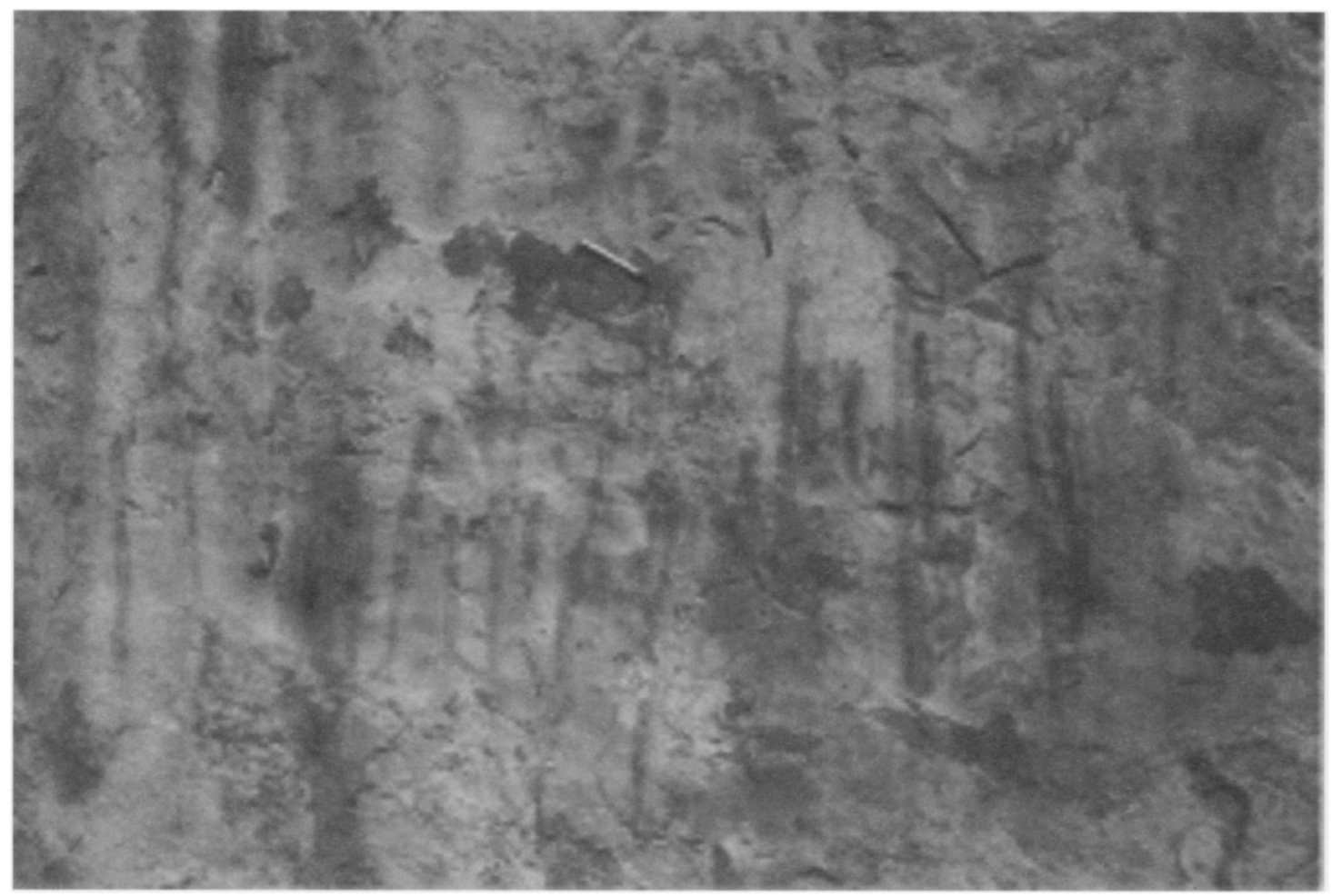

Figure 2. Hellgate Gulch (24BW9) images with pen tip pointing toward the figure that the AMS sample was removed from; image is approximately $1 \mathrm{~m}$ long.

Prehistoric rock art in the Big Belts exhibits its own distinct stratigraphy (Loubser 2001a; Scott et al. 2000). The first layer is the native limestone substrate. This layer is coated by a light, khaki-colored, case-hardened crust, which is the result of leaching and precipitation over millennia. The crust helps prevent the limestone surface from disintegrating. Red and orange pigment smears and designs were painted atop the case-hardened surface. Thin layers of calcium-oxalate, bonded dust, salt, and occasionally graffiti intermittently cover the painted images.

Four Big Belts rock art sites are the focus of this dating project-Hellgate Gulch (24BW9), Avalanche Mouth (24BW19), Gates of the Mountains (24LC27), and Big Log Gulch (24LC1707) (Figure 1). Table 1 lists the images that were sampled at each site for AMS dating and shows whether an AMS radiocarbon measurement was obtained. A brief description of the four sites follows.

\section{Hellgate Gulch (24BW9)}

This rock art site, measuring more than $22 \mathrm{~m}$ in length, lies near the mouth of Hellgate Gulch, a steep-sided limestone canyon. The Missouri River, now partly impounded by Canyon Ferry Reservoir, flows through the valley bottom some $5 \mathrm{~km}$ west of the site. The Hellgate Gulch site was recorded in detail during a Forest Service Passport in Time project in 1997 (Scott et al. 2000). More than 280 images are painted along the base of a vertical cliff face that rises over $20 \mathrm{~m}$ above the canyon floor. Images include dots, tally marks, hoofprints, groups of elongated human-like stick figures, handprints, rayed circles, crescents, zigzag lines, and geometric figures. While the majority of the rock art appears to belong to the Foothills Abstract tradition (elongated human figures, handprints, fingerlines, smears, and red wash), there are a few images (i.e., tally marks, rayed circles, zigzag line, dots) that more closely align with Eastern Columbia Plateau rock art (Keyser 1992). However, the Eastern Co- 
Table 1. Total AMS samples collected, image type that sample was collected from, estimated rock art tradition, and whether an AMS radiocarbon measurement was obtained.

\begin{tabular}{|c|c|c|c|c|}
\hline Sample & No. & Image Type; Location in Site & Rock Art Tradition & AMS Date \\
\hline $\begin{array}{l}\text { 24BW9 } \\
\text { Hellgate } \\
\text { Gulch }\end{array}$ & 1 & $\begin{array}{l}\text { Dot figure; dot is located on } \\
\text { panel with } 22 \text { fingerlines and } 13 \\
\text { other dots; sample located at far } \\
\text { eastern end of site }\end{array}$ & $\begin{array}{l}\text { Eastern Columbia } \\
\text { Plateau }\end{array}$ & No \\
\hline $\begin{array}{l}\text { 24BW9 } \\
\text { Hellgate } \\
\text { Gulch }\end{array}$ & 2 & $\begin{array}{l}\text { Sample taken from ray of rayed } \\
\text { circle; rayed circle is one of two } \\
\text { found next to each other }\end{array}$ & $\begin{array}{l}\text { Eastern Columbia } \\
\text { Plateau }\end{array}$ & No \\
\hline $\begin{array}{l}\text { 24BW9 } \\
\text { Hellgate } \\
\text { Gulch }\end{array}$ & 3 & $\begin{array}{l}\text { Elongated anthropomorph figure, } \\
\text { sample taken from head portion } \\
\text { of figure; figure near center of site }\end{array}$ & Foothills Abstract & Yes \\
\hline $\begin{array}{l}\text { 24BW19 } \\
\text { Avalanche } \\
\text { Mouth }\end{array}$ & 4 & Red smear-no identifiable image & Foothills Abstract & Yes \\
\hline $\begin{array}{l}24 \mathrm{LC} 27 \\
\text { Gates of } \\
\text { the Mountains }\end{array}$ & 5 & $\begin{array}{l}\text { Ungulate figure (deer or bison), } \\
\text { from hind portion of figure; figure } \\
\text { on panel with cross figure and } \\
\text { fingerlines }\end{array}$ & $\begin{array}{l}\text { Eastern Columbia } \\
\text { Plateau }\end{array}$ & No \\
\hline $\begin{array}{l}24 \mathrm{LC} 27 \\
\text { Gates of } \\
\text { the Mountains }\end{array}$ & 6 & $\begin{array}{l}\text { Handprint figure; handprint } \\
\text { located near ungulate figure }\end{array}$ & Foothills Abstract & No \\
\hline $\begin{array}{l}24 \mathrm{LC} 27 \\
\text { Gates of } \\
\text { the Mountains }\end{array}$ & 7 & $\begin{array}{l}\text { Red smear north of human-like } \\
\text { horned figure, smear appears to } \\
\text { be part of red wash }\end{array}$ & Foothills Abstract & Yes \\
\hline $\begin{array}{l}24 \mathrm{LC} 27 \\
\text { Gates of } \\
\text { the Mountains }\end{array}$ & 8 & $\begin{array}{l}\text { Red smear-no identifiable image; } \\
\text { taken from northern end of site }\end{array}$ & Foothills Abstract & No \\
\hline $\begin{array}{l}\text { 24LC1707 } \\
\text { Big Log } \\
\text { Gulch }\end{array}$ & 9 & $\begin{array}{l}\text { Calcium oxalate sample covering } \\
\text { a large red smear; figure located } \\
\text { away }(3 \mathrm{~m}) \text { from main site panel }\end{array}$ & Foothills Abstract & Yes \\
\hline
\end{tabular}


lumbia Plateau images are confined to the far eastern portion of the site beneath a small overhang. No superimpositioning of images from the two traditions was noted at the Hellgate Gulch site. Although the site has not been tested, there is no obvious occupational debris below the panel.

Paint pigment color varies at the site from dark red and reddish-orange to a light orange. There is a distinct paint layer stratigraphy. An extensive red wash underlies portions of the cliff face with finger-painted and fine line images painted atop the wash. Many of the painted images were then scratched (a chert tool with a burin-like point was found in a cliff crevice), and paint was spattered over previously painted images, creating a halo effect. Mineralization and paint spatter inside the scratches indicates that they were made prehistorically. Two fingerline images appear to have been repainted as evidenced by a darker paint color coating the previously painted images (Loubser 2001:6). Three pigment samples were collected from a red dot, an elongated human-like figure, and a

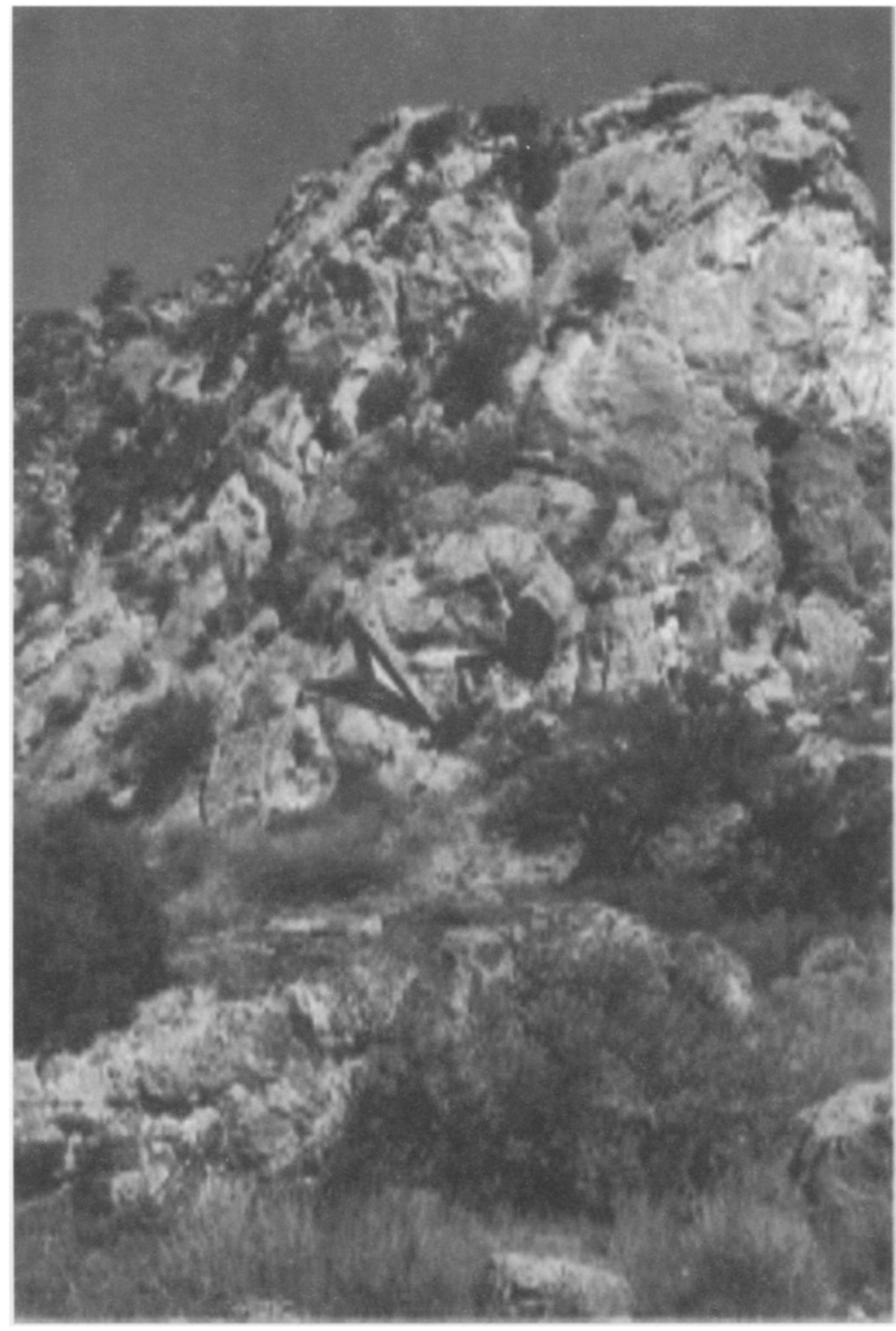

Figure 3. Avalanche Mouth site (24BW19) with arrow showing the location of the rock art site. rayed circle (Table 1). Only the sample from the head portion of one of twelve elongated human-like figures contained enough carbon to produce an AMS radiocarbon measurement (Figure 2).

\section{Avalanche Mouth (24BW19)}

The Avalanche Mouth pictographs are nestled in a small alcove overlooking the entrance to Avalanche Gulch (Figure 3). The alcove's small size and steeply-pitched floor apparently precluded its use as a living area or shelter. Unlike the enclosed setting of the Hellgate Gulch pictographs, located $4 \mathrm{~km}$ to the north, site 24BW19 offers an expansive view of the Missouri River valley to the southeast. The pictographs are painted with reddish-orange pigment on a $3 \times 3 \mathrm{~m}$ panel and are comprised of handprints, smears, fingerlines, a turtle-like figure, dots, and a blocky, human-like figure. Scratches 


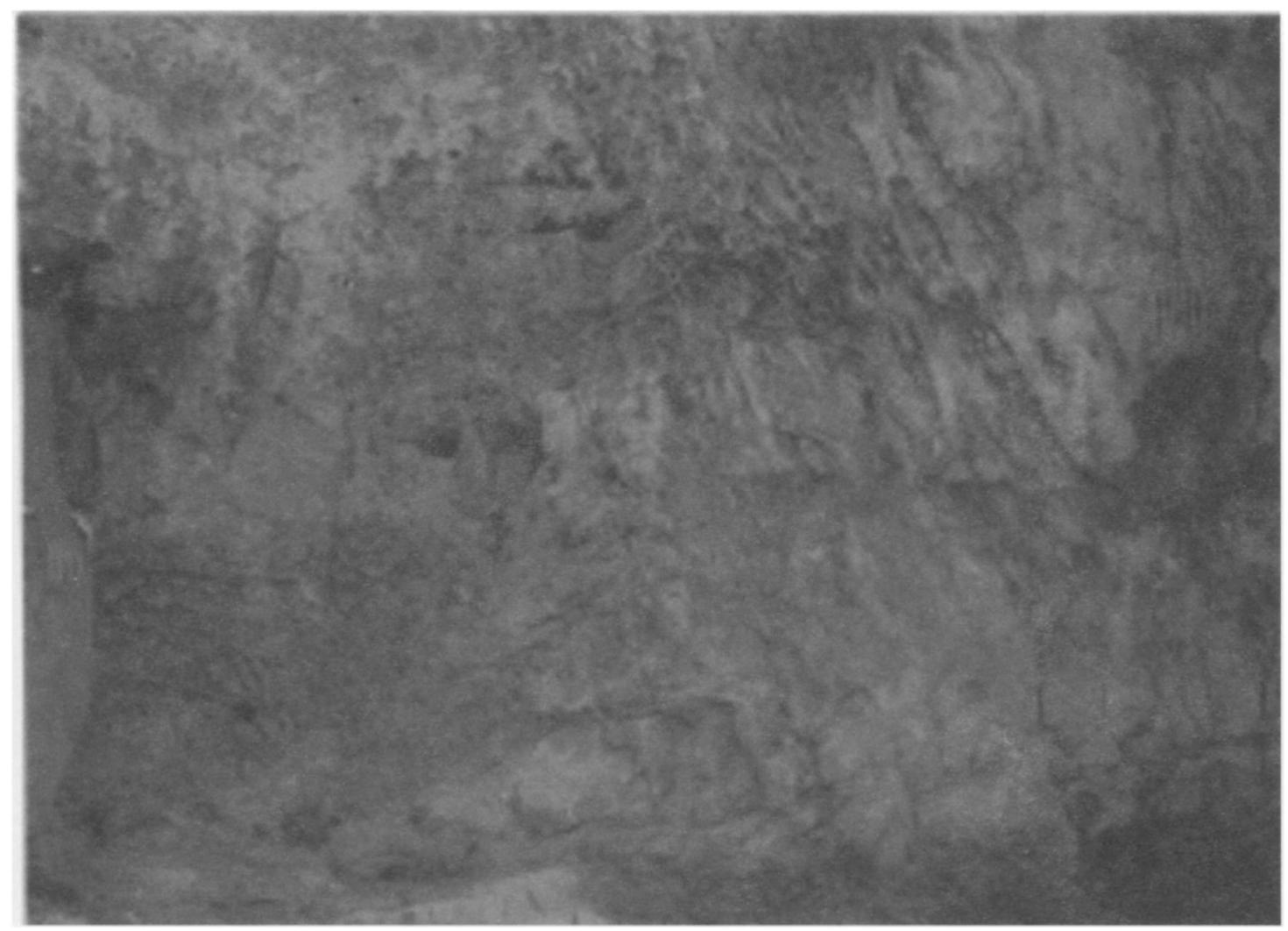

Figure 4. Gates of the Mountains site (24LC27) with person showing the location where the paint pigment sample was collected that yielded an AMS radiocarbon measurement.

through the pigment are present on several images. Mineralization within the scratches suggests they were made prehistorically. Small wavy lines within the handprints suggest that they are the finger and handprints of specific individuals. With the exception of the dot figures, all images found at the site are characteristic of the Foothills Abstract tradition.

Similar to the Hellgate Gulch site, the person(s) that used this site spread a red paint wash across the alcove walls before finger-painted images and hand-finger smears were applied. One pigment sample was obtained from an indistinguishable red smear that appears to have been part of the original underlying pigment wash. An AMS radiocarbon date was obtained from the pigment smear.

\section{Gates of the Mountains (24LC27)}

Site $24 \mathrm{LC} 27$ is situated above the Missouri River (now upper Holter Lake) in the massive limestone cliffs that characterize the scenic Gates of the
Mountains area (Figure 4). The river is a $25 \mathrm{~m}$ vertical drop below the site. The Gates of the Mountains pictographs consist of two separate panels in small overhangs located $10 \mathrm{~m}$ apart. The northwest shelter contains more than 170 images made up of paint smears, thick short lines, and an abundance of indecipherable paintings (Loubser 2004). Some smears emanate from natural holes in the rock, and all images were painted with reddish-orange pigment. The southeast shelter exhibits tally marks, large areas of underlying pigment wash, snake-like figures, horned human-like figures, handprints, dots, circles, and a solid painted large animal figure. Rock art stratigraphy at the site is complex. Some superimposition is apparent, but some images stand alone. The large animal-like figure and a few tally marks show evidence of overpainting, as suggested by the presence of lighter or darker paint colors coating the previously painted figures (Loubser 2004:78). Similar to the Hellgate Gulch site, the southeast 
shelter of 24LC27 appears to contain rock art representative of both the Foothills Abstract and Eastern Columbia Plateau rock art traditions. Eastern Columbia Plateau images appear to be superimposed over Foothills Abstract tradition smear images. Keyser and Klassen (2001) noted a strong tendency for Columbia Plateau images to occur at preexisting Foothills Abstract tradition sites, with the Plateau images painted over the Foothills motifs or as separate panels. Using pictograph content, placement, and regional ethnographic contexts, Loubser (2004:78-81) proposed that non-shaman initiates used the northwest shelter whereas both shamans and initiates used the northeast shelter.

The southeast shelter is highly visible from Holter Lake and is featured in a commercial boat tour through the Gates of the Mountains area. It is also attracting increased on-site visitation in part due to the Lewis and Clark Bicentennial. Most images in the southeast shelter are extremely friable, and painted spalls can be observed on the floor of the shallow shelter below the panel. Paint samples were collected from a solid-painted animal figure, a handprint, and two red wash smears (Table 1). The solid-painted animal figure was the only figure sampled where discernable prehistoric overpainting was noted. Only the sample taken from one of the red smears, located about $10 \mathrm{~cm}$ away from a horned human-like figure, produced an AMS date. The red smear appears to underlie the humanlike figure (Jannie Loubser, personal communication 2004).

\section{Big Log Gulch (24LC1707)}

Site $24 \mathrm{LC} 1707$ is located near the mouth of a small limestone canyon near Beaver Creek, just 2 $\mathrm{km}$ from the Missouri River (Figure 5). This small rockshelter's interior measures $8 \mathrm{~m}$ wide and $4 \mathrm{~m}$ deep to the back wall. The floor is flat and may contain occupational debris associated with the rock art, but the site has not been tested. Only ten distinct images - tally marks, smears, a cross, and two

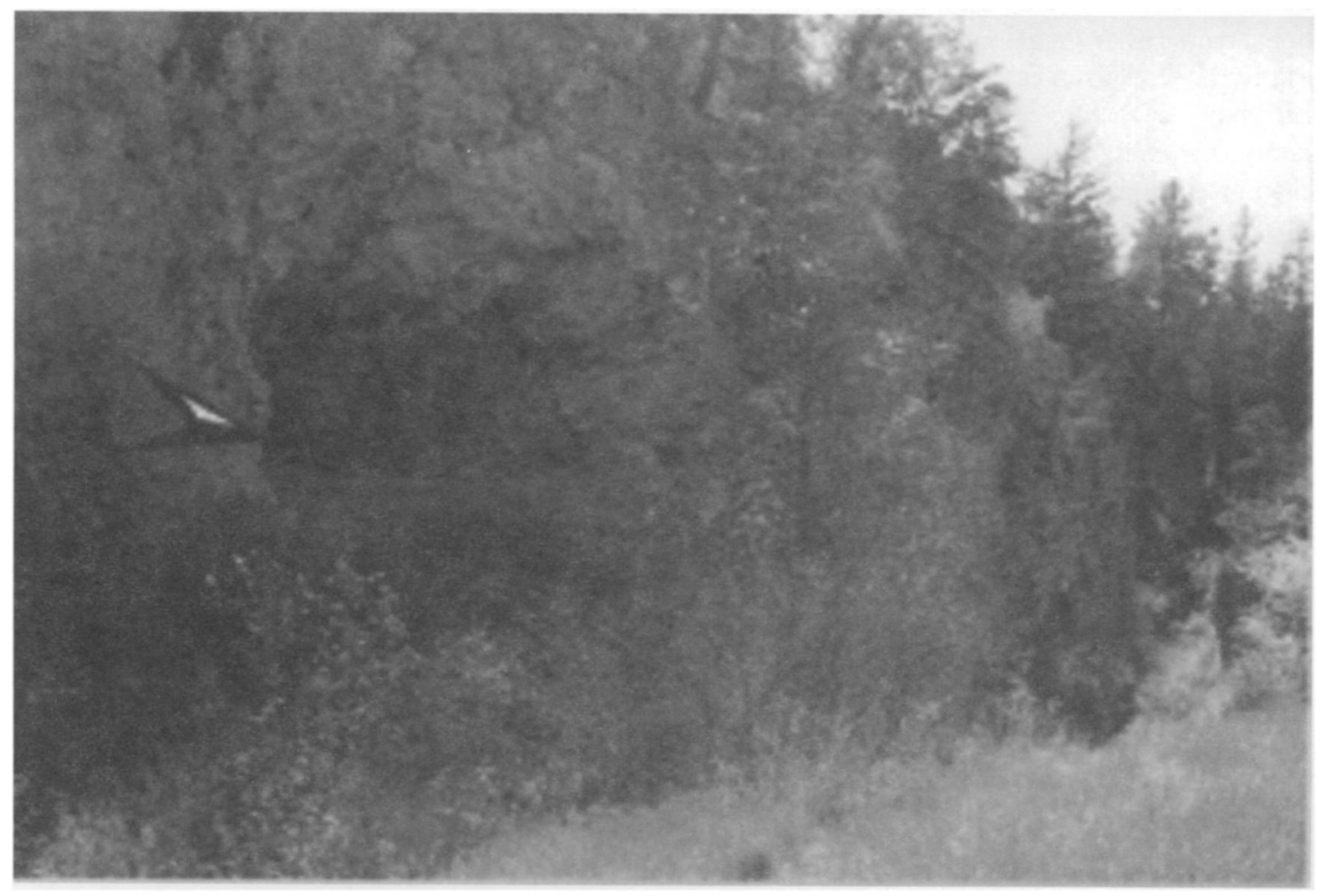

Figure 5. Big Log Gulch site (24LC1707) with arrow showing the location where the oxalate accretion sample was collected. The majority of the painted figures occur on the opposite side of the shelter to the right of the arrow. 
stylized anthropomorphs-are present. All are painted with orange pigment. In contrast to the preceding sites, Big Log Gulch does not have a red pigment wash or the superimposition of painted images and, in fact, the art has strong Columbia Plateau overtones (i.e., tally marks, see Keyser 1992). However, the smears present at the site are characteristic of Foothills Abstract tradition art. These red smears are located on a side wall opposite the small cluster of distinct, Columbia Plateau-like, pictographs.

Several images are in the process of exfoliation, but the pieces were not large enough for AMS dating. Of the seven panels identified at the site, two have calcium oxalate accretions that coat the painted images. A sample from a calcium oxalate accretion covering a red smear produced an AMS date.

\section{ROCK ART DATING}

The development of AMS in 1977 made it possible to radiocarbon date miniscule amounts of carbon samples that would not be datable by conventional radiocarbon techniques (Bennett et al. 1977; Muller 1977; Nelson et al. 1977). It was a decade later, however, before the Oxford radiocarbon laboratory first employed AMS to radiocarbon date a charcoal pictograph from South Africa (Van der Merwe et al. 1987). The laboratory at Texas A\&M University has radiocarbon dated more than 70 charcoal paintings from Angola, Argentina, Australia, Belize, Brazil, France, Guatemala, Russia, and Spain, as well as in Arizona, California, Colorado, Idaho, Missouri, Utah, and Wisconsin from the United States (e.g., see Rowe 2001). AMS has also been used to radiocarbon date some of the spectacular charcoal paintings in France and Spain (see Clottes 2001:469). Other laboratories have also dated charcoal pigments (see Rowe 2001 for a listing of dates through 2000). Most radiocarbon dates on rock art worldwide have been accomplished on charcoal paintings and on "beeswax" paintings in Australia (Nelson et al. 1995, 2000).

Most rock paintings worldwide are made from inorganic pigments instead of charcoal. Various shades of reds, oranges, browns, and yellows are almost invariably iron oxide/hydroxide minerals, and black is often manganese oxides/hydroxides. No inorganic materials (except calcium oxalate ac- cretions sometimes associated with pictographs, usually occurring as coating above or below pictographs, or both) can be dated by radiocarbon analysis. But pictographs with inorganic pigments potentially can be radiocarbon dated if organic matter was added to the paints initially. The development of plasma-chemical extraction combined with AMS allowed the first radiocarbon ages on inorganic-pigmented rock art paintings (Russ et al. 1990; see Rowe 2001).

Plasma-chemical extraction collects organic carbon from ancient pictograph paints for radiocarbon dating without interferences from carbon-containing minerals. Oxygen plasma converts organic material in paint samples to carbon dioxide, which is then collected for AMS radiocarbon dating. Oxygen plasma is electrically excited oxygen gas that is reactive with organic matter, but at low enough temperatures $\left(\leq 150^{\circ} \mathrm{C}\right)$ that carbon-containing minerals do not decompose (Chaffee, Hyman, and Rowe 1994; Russ et al. 1992). Operating at low temperatures alleviates problems caused by the common presence of carbonates and oxalates in rock art samples (and in many other archaeological samples as well). In contrast, combustion is typically used to collect carbon for radiocarbon dating. Occurring at about $750^{\circ} \mathrm{C}$, combustion will decompose any carbon-containing minerals and incorporate ${ }^{14} \mathrm{C}$-free contamination into the dated carbon sample if these minerals are not first sufficiently removed (Armitage et al. 2001; Hedges et al. 1998).

Our approach to dating pictographs relies upon the presence of organic carbon from (a) charcoal pigments or (b) from added binder/vehicle organic components. Plasma-chemical extraction is the only direct technique for dating pictographs painted with inorganic pigments. Charcoal and other organic pigments are also datable with plasma-chemical extraction and AMS radiocarbon measurement. To date, the chemical identification of organic paint binders in ancient paint samples has met with only limited success (e.g., Loy et al.1990; Watchman 1993), and was not attempted as part of this study. However, the plasma-chemical extraction method for dating pictographs appears to be successful as indicated by comparison of our radiocarbon results with age ranges expected on the basis of archaeological inference (e.g., see Figures 3 and 4 in Rowe and Steelman 2002). 


\section{EXPERIMENTAL PROCEDURE}

Eight red (iron ochre) paint samples from the Avalanche Mouth (24BW19), Gates of the Mountains (24LC27), and Hellgate Gulch (24BW9) pictograph sites were chosen for plasma-chemical extraction of carbon followed by AMS radiocarbon dating. Wearing latex gloves, we (Rowe, Scott) used a new sterile surgical scalpel blade to collect each sample. Samples were wrapped in aluminum foil and stored in plastic bags. In addition, background samples were collected consisting of unpainted rock and accretion minerals that were located directly adjacent to each paint sample. These background samples were taken to determine the presence, if any, of organic contamination in the rock substrate, a necessary precaution when dating pictographs. A calcium oxalate accretion sample that was deposited on top of a red pigment smear at Big Log Gulch (24LC1707) was also collected for potential AMS radiocarbon dating.

We observed overpainting in only one collected sample, an animal-like figure at 24LC27. The overpainting occurred toward the center of the figure, and the sample was removed toward the hind portion of the figure where no overpainting was detected. This sample did not contain sufficient carbon to yield a radiocarbon measurement. Although overpainting of images is a potential problem, the authors (Steelman and Rowe) have seen possible evidence for its occurrence only twice in North American rock art paintings. It was unclear whether these examples, in thin sections of paint flakes, were truly overpainting or simply "surface preparation." For the Montana samples, we did not prepare thin sections, but the edges of the paint flakes were examined with an optical stereoscope and no distinct paint layers or overpainting were observed.

In the laboratory, paint samples were scraped from small chunks of rock substrates and pulverized with an agate mortar and pestle. This powder was viewed under an optical microscope to look for any extraneous materials such as fibers or rootlets. None were seen.

Paint samples were then chemically pretreated with a $4 \%(w / w)$ sodium hydroxide solution in a $50 \pm 5^{\circ} \mathrm{C}$ ultrasonic water bath for one hour as a precaution against potential humic acid contamination.
There was no color change in the supernatant liquid. In fact, for rock art paint samples, we have never observed the orange-brown color change that would indicate the presence of humic acids. This implies, but does not prove, the absence of humic acid in the samples. Because humic acids are unlikely to adhere to an exposed surface, the necessity of these base washes with our technique is questionable. Rinsed samples were filtered through binder-free borosilicate glass filters that had been baked overnight at $\sim 600^{\circ} \mathrm{C}$ to remove organic contamination. Filtered samples were dried at $110^{\circ} \mathrm{C}$ before the plasma oxidation process.

We (Rowe, Steelman) routinely omit traditional acid washes used by other laboratories, as they are unnecessary with plasma-chemical extraction (Chaffee, Hyman, and Rowe 1994; Pace et al. 2000; Russ et al. 1992). In our procedure, decomposition of carbon-containing minerals such as carbonates and oxalates into carbon dioxide is prevented by running the plasmas at low-temperature $\left(<150^{\circ} \mathrm{C}\right)$. With plasma-chemical extraction, only organic material is removed for radiocarbon measurements. For these samples from Montana, that almost certainly contain oxalates, plasma-chemical extraction is more suitable than combustion for obtaining accurate radiocarbon dates because acid washes may not completely remove oxalate minerals (Armitage et al. 2001; Hedges et al. 1998). If not removed, oxalate would be incorporated into the dated material by combustion, distorting the date.

The plasma-chemical extraction method has been used repeatedly to collect organic carbon from rock painting samples for radiocarbon dating and has been described in detail (Rowe and Steelman 2002). Organic carbon in a paint sample is converted to carbon dioxide during plasma-chemical extraction. This carbon dioxide is reduced over a metal catalyst to form a graphite target for $\mathrm{AMS}{ }^{14} \mathrm{C}$ measurement at Lawrence Livermore National Laboratory's Center for Accelerator Mass Spectrometry (CAMS).

Background (unpainted rock) samples underwent the same procedure as paint samples. The collection of background samples is problematic, as they may not represent true "blank" samples in a chemical sense. However, this is as close as we can come to obtaining a "true" blank. Background (non- 
pigmented) samples were taken from numerous locations near each sampled painting. This technique helps to average heterogeneities to some extent. There was negligible organic carbon in background samples to affect radiocarbon dates on these rock paintings. Less than $0.002 \mathrm{mg}$ of carbon was generated by oxidizing the background samples under the same conditions as the paint samples. Thus, the radiocarbon ages obtained are expected to reliably represent the age of the organic binder in the paint.

For the one accretion sample from site $24 \mathrm{LC} 1707$, the presence of calcium oxalate (whewellite, $\mathrm{CaC}_{2} \mathrm{O}_{4} \cdot \mathrm{H}_{2} \mathrm{O}$, and weddellite, $\mathrm{CaC}_{2} \mathrm{O}_{4} \cdot 2 \mathrm{H}_{2} \mathrm{O}$ ) was confirmed by X-ray diffraction. To remove calcite, approximately $6.7 \mathrm{mg}$ of the powdered accretion sample was placed in $5 \%(\mathrm{w} / \mathrm{w})$ phosphoric acid for two days. Carbonates effervesced and were dissolved by the acid. The purified calcium oxalate mineral was sent to CAMS for combustion and AMS radiocarbon dating.

\section{RESULTS AND DISCUSSION}

Of the eight pigment samples collected from Avalanche Mouth, Hellgate Gulch, and Gates of the Mountains, radiocarbon results were obtained from three of the samples (Table 2). There were insufficient amounts of organic carbon present for radiocarbon measurement in the other five paint samples. Approximately $0.05 \mathrm{mg}$ or more of carbon is required from a paint sample to produce a viable AMS date. Another AMS date was obtained from an oxalate accretion at the Big Log Gulch site. Paint pigment underlying the oxalate was not collected because the image was not exfoliating from the rock surface.
Calibrations were performed using OxCal v3.5 to convert radiocarbon ages to calendar year ranges (Bronk Ramsey 2002; Stuiver et al.1998). Radiocarbon results for the three paintings, along with the $2 \sigma$ age ranges, corresponding probabilities, and specific dates are included in Table 2. The three dates are statistically indistinguishable, suggesting that painting activity at these sites likely occurred within a narrow time range (Figure 6). The pictograph images from the three sites were painted between 650 and $990 \mathrm{cal}$ A.D.

The radiocarbon date of $1440 \pm 45$ B.P. for a calcium oxalate accretion from site $24 \mathrm{LC} 1707$ is a minimum age for the rock painting that it covers. The red painting underneath this accretion is older than 530 cal A.D. Calcium oxalate crusts are common as accretions on limestone surfaces. Their source of carbon is assumed to be atmospheric carbon dioxide, meaning that oxalate carbon can be radiocarbon dated to determine when the oxalate was formed (Beazley et al. 2002). This approach to constraining ages of pictographs by radiocarbon dating oxalate accretions encasing paint layers has been used previously (Hedges et al. 1998; Russ et al. 1996, 1999, 2000; Steelman et al. 2002; Watchman 1991; Watchman et al. 2000).

As a group, the three AMS radiocarbon dates from the Avalanche Mouth, Hellgate Gulch, and Gates of the Mountains pictograph sites are statistically coeval and tightly range in age from 1170 to 1280 years B.P. In contrast, the slightly older oxalate date lying atop the paint smear at another site, Big Log Gulch, provides only a minimum date of 1440 B.P. Its chronological value is relative, and

\section{$1170 \pm 45 B P$ \\ $1225 \pm 50 \mathrm{BP}$ \\ $1280 \pm 50 \mathrm{BP}$ \\ 200CalAD 400CalAD 600CalAD 800CalAD 1000CalAD 1200CalAD Calibrated date}

Figure 6. Calibrated age ranges for three Montana rock art paintings (Bronk Ramsey 2002, Stuiver et al. 1998). 
Table 2. AMS radiocarbon results for rock art images from the Big Belt Mountains of west-central Montana.

\begin{tabular}{|c|c|c|c|c|c|}
\hline Site & $\begin{array}{l}\text { Motif } \\
\text { (sample \#) }\end{array}$ & $\mu \mathrm{g}$ Carbon & AMS ID & $\begin{array}{l}\text { Radiocarbon Age } \\
\text { (years B.P.) }\end{array}$ & $\begin{array}{l}2 \sigma \text { Calibrated Age } \\
\text { A.D. (probability) }\end{array}$ \\
\hline $\begin{array}{l}\text { 24BW9 } \\
\text { Hellgate } \\
\text { Gulch }\end{array}$ & $\begin{array}{l}\text { Red } \\
\text { anthropomorph } \\
\text { (sample \#3) }\end{array}$ & 85 & 99065 & $1170 \pm 45$ & $\begin{array}{l}720-740(2.2 \%) \\
770-990(93.2)\end{array}$ \\
\hline $\begin{array}{l}\text { 24BW19 } \\
\text { Avalanche } \\
\text { Mouth }\end{array}$ & $\begin{array}{l}\text { Red smear-no } \\
\text { identifiable image } \\
\text { (sample \#4) }\end{array}$ & 76 & 99055 & $1225 \pm 50$ & $\begin{array}{l}680-900(91.8) \\
920-960(3.6)\end{array}$ \\
\hline $\begin{array}{l}24 \mathrm{LC} 27 \\
\text { Gates of } \\
\text { the Mountains }\end{array}$ & $\begin{array}{l}\text { Red smear north } \\
\text { of horned figure } \\
\text { (sample \#7) }\end{array}$ & 80 & 101902 & $1280 \pm 50$ & $650-890(95.4)$ \\
\hline $\begin{array}{l}\text { 24LC1707 } \\
\text { Big Log } \\
\text { Gulch }\end{array}$ & $\begin{array}{l}\text { Calcium oxalate } \\
\text { (sample \#9) }\end{array}$ & 79 & 95674 & $1440 \pm 45$ & $530-680(95.4)$ \\
\hline
\end{tabular}

any interpretive discussion would largely be speculative. Therefore, the following discussion is focused primarily on the three plasma-derived AMS radiocarbon dates.

For comparison, the three Big Belts dates are about 380 years older than a pictograph panel at Elk Creek Cave (24BH1501) in the Pryor Mountains of south central Montana (Chaffee, Loendorf, Hyman, and Rowe 1994). An AMS date of $840 \pm 50$ years B.P. (AA-8843) was obtained from a red paint smear associated with a solid-body anthropomorph. However, the four Big Belts rock art dates are significantly younger than a black-painted turtle image located on the back wall of Pictograph Cave near Billings, which produced three AMS dates that averaged to 2145 B.P. This is the oldest known painted image from the Northwestern Plains (Francis and Loendorf 2002:161).

All three AMS dates from the current study fall within the early Late Prehistoric Period in Northwestern Plains and Intermountain cultural chronologies (Frison 1991; McCracken 1978). Acknowledging that the temporal boundary between the Late Plains Archaic and Late Prehistoric periods is uneven across the Plains and Northern Rockies, the transition occurred roughly 2,000 to 1,500 years ago. Archaeologically, the Late Prehistoric period is marked by the appearance of small, side-notched arrow points and pottery, as well as an array of ground stone, bone, and shell tools and ornaments. The Late Prehistoric period was a time of growing cultural complexity and a period of increased rock art production (Keyser and Klassen 2001:48-52).

By virtue of their tight clustering, our AMS dates do not help set a temporal range for Foothills Abstract (or Eastern Columbia Plateau tradition) rock art within the Late Prehistoric or earlier time periods in this region. The dates demonstrate that the Foothills Abstract tradition was in vogue in central Montana during the initial Late Prehistoric period, as proposed by both Greer (1995) and Keyser and Klassen (2001:163-165). Further, during this period, Avonlea, Besant, and related archaeological complexes were evolving into, being replaced by, or becoming amalgamated with other complexes or cultural groups that used an array of small sideand corner-notched projectile point styles. Whether this period of cultural change has implications for central Montana rock art is unknown.

The Foothills Abstract tradition appears to dominate Big Belts, and central Montana, rock art during the Late Prehistoric period. However, as at- 
tested by the Big Log, Hellgate, and Gates of the Mountain pictographs, makers of Columbia Plateau rock art were also present in this region. The extant, and largely homogeneous, hunter-gatherer archaeological record offers little about cultural relationships and thus the larger cultural context of the central Montana rock art itself. Abundant Late Prehistoric period evidence is found in the foothills of the Big Belt Mountains (for example, a tipi ring site [24BW892] containing small side-notched points and a boulder with orange prehistoric paint smears lies directly below the Avalanche Mouth site), in nearby Canyon Ferry Reservoir (Greiser 1986), and adjacent mountain ranges (Davis et al. 1982).

The authorship of Foothills Abstract rock art is speculative. The Missouri River corridor was a busy prehistoric travel route, and several Indian groups also used the Missouri River-Helena Valley area during the protohistoric and historic periods (Knight 1989:145-156). The 1,200-year time lag between the Big Belts rock art dates and the Historic period preclude assigning an ethnic appellation with any certainty. Keyser and Klassen (2001:166) tentatively suggest that Kiowa and other Apachean groups might have produced Foothills Abstract rock art. Salish (Flathead) and Kutenai groups that may have resided on the east flanks of the Continental Divide during the Late Prehistoric period could be responsible for the Eastern Columbia Plateau-like art observed at three of our sample sites (see Greiser 1994:48-49). In fact, a pigment source highly valued by the Salish is located in the northern Big Belts (Teit 1930:340). Whether the Salish or Kutenai also produced Foothills Abstract art is more problematic because this rock art tradition is absent in their customary homeland of western Montana.

Our small AMS date sample precludes drawing many inferences about the dated images and their association with particular rock art traditions. However, all four dates come from images (one elongated human-like figure, three smears) that appear to belong to the Foothills Abstract tradition. Samples removed from images (i.e., dots, rayed circle, solid animal figure) that would fit within the Eastern Columbia Plateau rock art tradition failed to yield enough organic material to produce viable
AMS dates (Table 1). This might be a function of the different types of organic binders used by makers of Foothills Abstract and Columbia Plateau rock art, and thus has intriguing cultural connotations. It could also be attributed to the thicker amounts of paint used to produce Foothills Abstract washes, smears and designs and therefore the proportionately higher percentage of organic content in the paint binder.

Finally, it seems clear from the superimpositioning of images, scratching and spattering, and other evidence that the four AMS dates reflect a particular moment in time of rock art production during a vision quest, healing ceremony, or shaman's trance. Data from Hellgate Gulch and elsewhere in Montana (see Loendorf 1992:74-75; Scott et al. 2000) show that rock art images, and the rock surfaces on which they were painted, were "interactive," and paint was probably accrued and lost over many centuries via human scratching and abrasion. Therefore, the four AMS dates from this study may not capture the full use-life of these sites.

\section{CONCLUSIONS}

In 2002, eight pigment samples from four rock art sites in the Big Belt Mountains were the subject of plasma-extraction and subsequent AMS radiocarbon dating. All eight samples were removed from pigment that was exfoliating from painted images. Three of the pigment samples contained enough organic material for reliable dating. Two AMS dates were derived from paint washes or smears characteristic of Foothills Abstract tradition rock art. The third date came from the head of an elongated human-like stick figure at the Hellgate Gulch pictograph site. This image is characteristic of the Foothills Abstract tradition, although some stick figures do occur in Columbia Plateau rock art (Keyser 1992:36-37). A calcium oxalate sample coating a red pigment smear produced a fourth AMS date.

The three AMS dates cluster tightly at $1220 \pm 30$ years B.P. The calcium oxalate date is several hundred years earlier at $1440 \pm 45$ years B.P., but it only provides a minimal date for the underlying red paint smear. The absolute date of this image remains unknown. The dates provide a firm chronological positioning for the Foothills Abstract rock art tradition in the initial Late Prehistoric Period on the 
Northwestern Plains and adjacent Rocky Mountain region. It is likely that the panels themselves had a longer use-life, perhaps extending over many centuries. Further AMS dating could provide greater chronological separation among the various Foothills Abstract washes and images found at each site. For example, the extant dates are suggestive of a tight time span for smearing. Additional AMS dating could also shed light on the stylistic differences and temporal overlaps between Foothills Abstract and Eastern Columbia Plateau tradition rock art. The current hypothesis that Columbia Plateau images were painted after and atop Foothills Abstract tradition rock art could quickly be altered by successful dating of Columbia Plateau-like figurestally marks, rayed circles, and solid animal figuresat the sample sites or at other site locations.

AMS radiocarbon dating of rock art is still an experimental field of inquiry. There are a variety of analytical issues associated with pigment (paint binder) extraction, identification, contamination, and dating (see Russ et al. 1992; Watchman 1993). Thus, this project is one small step, and we acknowledge that further pigment sampling, analyses, and AMS dating are required to assess the accuracy of the dates reported herein. Because AMS dating is inherently destructive, careful and judicious sampling of exfoliating paint is required. Independent analyses and verification of the AMS dates is also necessary, whether through conventional archaeological testing or by other means.

In view of the growing public interest in rock art, and increasing site visitation, AMS radiocarbon dating and other rock art information should be part of on-site signing (if appropriate) and offsite displays, brochures, and interpretive media. As conservation studies from elsewhere suggest (Loubser 2001b), this effort could engender public appreciation of central Montana rock art and abate vandalism and other depreciative behavior.

\section{ACKNOWLEDGEMENTS}

This AMS rock art dating project was partially supported with Forest Service-Lewis and Clark Bicentennial funding. National Science Foundation Archaeometry Grant No. 0209312 also provided partial support. Radiocarbon analyses were performed under the auspices of the U. S. DOE by the University of California, Lawrence Livermore Na- tional Laboratory under Contract No. W-7405-Eng48. Ruthann Armitage reviewed the manuscript and provided critical feedback on our AMS dating methods and analyses. Julie Francis, Jannie Loubser, and Jim Keyser also reviewed the manuscript and provided many helpful comments.

\section{REFERENCES}

Armitage, Ruth A., James E. Brady, Allan Cobb, John R. Southon, and Marvin W. Rowe

2001 Mass Spectrometric Radiocarbon Dates from Three Rock Paintings of Known Age. American Antiquity 66:471480.

Beazley, Melanie J., Richard D. Rickman, Debra K. Ingram, Thomas W. Boutton, and Jon Russ

2002 Natural Abundances of carbon isotopes $\left({ }^{14} \mathrm{C},{ }^{13} \mathrm{C}\right)$ in Lichens and Calcium Oxalate Pruina: Implications for Archaeological and Paleoenvironmental Studies. Radiocarbon 44:675-683.

Bennett, C.L., R.. Beukens, M.R. Clover, H.E. Gove, R.B. Liebert, A.E. Litherland, K.H. Purser, and W.E. Sondheim

1977 Radiocarbon Dating Using Electrostatic Accelerators: Negative Ions Provide the Key. Science 198:508-510.

Bronk Ramsey, Christopher

2002 OxCal Program v3.5. University of Oxford Radiocarbon Accelerator Unit. Available at www.rlaha.ox.ac.uk/ oxcal/oxcal.htm.

Chaffee, Scott, Lawrence L. Loendorf, Marian Hyman, and Marvin W. Rowe

1994 Dating a Pictograph in the Pryor Mountains, Montana. Plains Anthropologist 39:195-201.

Chaffee, Scott D, Marian Hyman, and Marvin W. Rowe

1994 Radiocarbon Dating of Rock Paintings. In New Light on Old Art: Recent Advances in Hunter-Gatherer Rock Art Research, edited by David S. Whitley and Lawrence L. Loendorf, pp. 9-12. Institute of Archaeology Monograph 36, University of California, Los Angeles.

Clottes, Jean.

2001 Paleolithic Europe. In Handbook of Rock Art Research, edited by David S. Whitley, pp. 459-481. Altamira Press, Walnut Creek.

Davis, Carl M.

2001 Trial By Fire: 2000 Season. In Helena National Forest Annual Heritage Resource Compliance Report: 2000 Field Season, pp. 127-138, USDA Forest Service, Helena National Forest, Montana.

Davis, Leslie B., Stephen A. Aaberg, Michael Wilson and Robert Ottersberg

1982 Stone Circles in the Montana Rockies: Systematic Recovery and Cultural Ecological Inference. Department of Sociology, Montana State University, Bozeman.

Francis, Julie E., and Lawrence L. Loendorf

2002 Ancient Visions, Petroglyphs and Pictographs of the Wind River and Bighorn Country, Wyoming and Montana. University of Utah Press, Salt Lake City.

Frison, George C.

1991 Prehistoric Hunters of the High Plains. Second Edition, Academic Press, San Diego. 
Greer, Mavis

1995 Archaeological Analysis of Rock Art Sites in the Smith River Drainage of Central Montana. Ph.D. dissertation, University of Missouri, Columbia.

Greer, Mavis and John Greer

1997 Montana Rock Art: 1997. Greer Services, Casper, Wyoming.

2001 Rock Art Reconnaissance of Selected Areas of the Cave Gulch Wildfire Area, Helena National Forest, Lewis \& Clark County, Montana. Greer Services, Casper, Wyoming.

2003 A Test for Shamanic Trance in Central Montana Rock Art. Plains Anthropologist 48(186):105-120.

Greiser, Sally T.

1986 Artifact collections from ten sites at Canyon Ferry Reservoir. Archaeology in Montana 27(1\&2):1-190.

1994 Late Prehistoric Cultures on the Montana Plains. In Plains Indians, A.D. 500-1500, edited by Karl H. Schleiser, pp. 34-55. University of Oklahoma Press, Norman.

Hedges, Richard E.M, Christopher Bronk Ramsey, G.J. Van Klinken, P.B. Pettitt, Christina Nielsen-Marsh, Alberto Etchegoyen, J.O. Fernandez Niello, M.T. Boschin, and A.M. Llamazares

1998 Methodological Issues in the ${ }^{14} \mathrm{C}$ Dating of Rock Paintings. Radiocarbon 40:35-44.

Keyser, James D.

1992 Indian Rock Art of the Columbia Plateau. University of Washington Press, Seattle.

Keyser, James D., and Michael A. Klassen

2001 Plains Indian Rock Art. University of Washington Press, Seattle.

Knight, George C.

1989 Prehistoric Overview. Helena and Deerlodge National Forests, Ecological and Cultural Prehistory. USDA Forest Service, Region One.

Loendorf, Lawrence L.

1992 AMS 14 Carbon and CR Age Estimates for Two Montana Rock Art Sites. Archaeology in Montana 33:2, pp. 71-83.

Loubser, Jannie H.R.

2001a Guarding the Gates: The Conservation and Management of Seven Rock-Art Sites, Big Belt Mountains, Southwestern Montana. New South Associates, Stone Mountain, Georgia.

2001b Management Planning for Conservation. In Handbook of Rock Art Research, edited by David S. Whitley, pp 80 115. Altamira Press, Walnut Creek, California.

2002 Conservation Assessment of Seven Rock Art Sites with the Big Belt Mountains, Helena National Forest, Montana. New South Associates, Stone Mountain, Georgia.

2004 Rock Art Recording at 24LC27, Helena National Forest, The Gates of the Mountains, Big Belt Mountains, Montana. New South Associates, Stone Mountain, Georgia.

Loy, T.H., R. Jones, D.E. Nelson, N. Meehan, J. Vogel, J. Southon, and R. Cosgrove

1990 Accelerator Radiocarbon Dating of Human Blood Proteins in Pigments from Late Pleistocene Art Sites in Australia. Antiquity 64:110-116.

McCracken, Harold H., editor

1978 The Mummy Cave Project in Northwestern Wyoming.
Buffalo Bill Historical Center, Cody, Wyoming.

Muller, Richard A.

1977 Radioisotope Dating with a Cyclotron. Science 196:489-494.

Nelson, D. Erle, G. Chaloupka, C. Chippendale, M.S.

Alderson, and John R. Southon

1995 Radiocarbon Dates for Beeswax Figures in the Prehistoric Rock Art of Australia. Archaeometry 37:151-156.

Nelson, D. Erle, R.G. Korteling, and W.R. Stott

1977 Carbon-14: Direct Detection at Natural Concentrations. Science 198:507-508.

Nelson, D. Erle, John R. Southon and C. Takahashi

2000 Radiocarbon Dating of the Wax Art. In The Beeswax Art of Northern Australia. A CD produced at the Simon Fraser University, Burnaby, Canada, edited by D. E. Nelson, pp. 44-63. Copyright by Archaeology Department, Simon Fraser University.

Pace, Mary F.N., Marian Hyman, Marvin W. Rowe, and John R. Southon

2000 Chemical Pretreatment on Plasma-Chemical Extraction for ${ }^{14} \mathrm{C}$ Dating of Pecos River Genre Rock Paintings. In American Indian Rock Art, vol. 24, edited by F.G. Bock, pp. 95-102. American Rock Art Research Association, Tucson, Arizona.

Rowe, Marvin W.

2001 Dating by AMS Radiocarbon Analysis. In Handbook of Rock Art Research, edited by David S. Whitley, pp. 139-166. Altamira Press, Walnut Creek.

Rowe, Marvin W. and Karen L. Steelman

2002 Radiocarbon Dating of Rock Paintings Using PlasmaChemical Extraction. American Laboratory 34:15-20.

Russ, Jon, Marian Hyman, Harry J. Shafer, and Marvin W. Rowe

1990 Radiocarbon Dating of Prehistoric Rock Paintings by Selective Oxidation of Organic Carbon. Nature 348:710 711.

Russ, Jon, Marian Hyman, and Marvin Rowe.

1992 Direct Radiocarbon Dating of Rock Art. Radiocarbon 34:867-872.

Russ, Jon, Russell L. Palma, David H. Loyd, Thomas W. Boutton, and Michael A. Coy

1996 Origin of the Whewellite-Rich Rock Crust in the Lower Pecos Region of Southwest Texas and its Significance to Paleoclimate Reconstructions. Quaternary Research 46:27-36.

Russ, Jon, Warna D. Kaluarachchi, Louise Drummond, and Howell G.M. Edwards

1999 The Nature of a Whewellite-Rich Rock Crust Associated with Pictographs in Southwestern Texas. Studies in Conservation 44:91-103.

Russ, Jon, David H. Loyd, and Thomas W. Boutton

2000 A Paleoclimate Reconstruction for Southwestern Texas using Oxalate Residue from Lichen as a Paleoclimate Proxy. Quaternary International 67:29-36.

Scott, Sara A., and Carl M. Davis

2004 Rock Art Conservation, Dating and Protection on the Helena National Forest, West-Central Montana. Paper presented at the 31st American Rock Art Research Association Conference, Casas Grandes, Chihuahua, Mexico.

Scott, Sara A., James D. Keyser, and Jannie H.N. Loubser 2000 The Hellgate Pictographs: Shamanism and Ritual in 
West Central Montana. Archaeology in Montana 41(1):3152.

Steelman, Karen L., Richard Rickman, Marvin W. Rowe, Thomas W. Boutton, Jon Russ, and Niéde Guidon 2002 Accelerator Mass Spectrometry Radiocarbon Ages of an Oxalate Accretion and Rock Paintings at Toca do Serrote da Bastiana, Brazil. In Archaeological Chemistry $V$, edited by Kathryn A. Jakes, pp. 22-35. American Chemical Society, Washington, DC.

Stuiver, Minze, Paula J. Reimer, Edouard Bard, J. Warren Beck, G. S. Burr, Konrad A. Hughen, Bernd Kromer, Gerry McCormac, Johannes van der Plicht, and Marco Spurk

1998 INTCAL98 Radiocarbon Age Calibration 24000-0 cal BP. Radiocarbon 40:1041-1083.

Teit, James A.

1930 Salishan Tribes of the Western Plateau. Annual Report of the Bureau of American Ethnology for 1927-1928. Smithsonian Institution, Washington, D.C.
Van der Merwe, N.J., J. Sealy, and R. Yates

1987 First Accelerator Carbon-14 Date for Pigment from a Rock Painting. South African Journal of Science 83:5657.

Watchman, Alan L.

1991 Age and Composition of Oxalate-Rich Crusts in Northern Territory, Australia. Studies in Conservation 36:24 32.

1993 Perspectives and Potentials for Absolute Dating Prehistoric Rock Paintings. Antiquity 87:58-65.

Watchman, Alan L., Bruno David, I.J. McNiven, and Josephine M. Flood

2000 Micro-archaeology of Engraved and Painted Rock Surface Crusts at Yiwarlarlay (the Lightning Brothers site), Northern Territory, Australia. Journal of Archaeological Science 27:315-325. 